Research Article

\title{
Protective Effect of Coconut Oil Meal Phenolic Antioxidants against Macromolecular Damage: In Vitro and In Vivo Study
}

\author{
A. N. Karunasiri ${ }^{\mathbb{D}},{ }^{1}$ C. M. Senanayake, ${ }^{1,2}$ H. Hapugaswatta ${ }^{1},{ }^{1}$ N. Jayathilaka $\left(\mathbb{D},{ }^{1}\right.$ \\ and K. N. Seneviratne $\mathbb{D}^{1}$ \\ ${ }^{1}$ Department of Chemistry, Faculty of Science, University of Kelaniya, Kelaniya, Sri Lanka \\ ${ }^{2}$ Department of Biosystems Technology, Faculty of Technology, University of Sri Jayewardenepura, Nugegoda, Sri Lanka
}

Correspondence should be addressed to N. Jayathilaka; njayathi@kln.ac.lk and K. N. Seneviratne; kapilas@kln.ac.lk

Received 27 April 2020; Accepted 8 June 2020; Published 29 June 2020

Academic Editor: Ioannis G. Roussis

Copyright (c) 2020 A. N. Karunasiri et al. This is an open access article distributed under the Creative Commons Attribution License, which permits unrestricted use, distribution, and reproduction in any medium, provided the original work is properly cited.

\begin{abstract}
Coconut oil meal, a cheap by-product of coconut oil production, is a rich source of phenolic antioxidants. Many age-related diseases are caused by reactive oxygen species- (ROS-) induced damage to macromolecules such as lipids, proteins, and DNA. In the present study, the protective effect of the phenolic extract of coconut oil meal (CMPE) against macromolecular oxidative damage was evaluated using in vitro and in vivo models. Sunflower oil, bovine serum albumin (BSA), and plasmid DNA were used in the in vitro study, and thiobarbituric acid reactive substances (TBARS), protein carbonyl, and nicked DNA were evaluated as oxidation products. The inhibitory effect of CMPE against $\mathrm{H}_{2} \mathrm{O}_{2}$-induced macromolecular damage was evaluated using cultured HEp-2 cells. The results indicate that CMPE inhibits macromolecular damage both in vitro and in vivo. In addition, CMPE regulates redox status of HEp-2 cells under oxidative stress conditions by maintaining higher reduced glutathione levels. There was no significant difference in the expression of glutathione peroxidase in stressed and unstressed cells suggesting that CMPE regulates the cellular oxidative stress responses without affecting the expression of oxidative stress response genes. Oral feeding of Wistar rats with CMPE improves the serum and plasma antioxidant status without causing any toxic effects.
\end{abstract}

\section{Introduction}

Oxidative stress-induced modification of macromolecules such as lipids, proteins, and DNA has been identified as a risk factor in various diseases such as cardiovascular disease, neurodegenerative disorders, and cancer [1]. Accumulation of high levels of ROS in cells causes cell toxicity and cell death, while low levels of ROS support cell growth and proliferation [2]. In addition to the health effects caused by breakdown of lipids due to ROS-mediated peroxidation, the resultant products of lipid peroxidation such as malondialdehyde (MDA) and 4-hydroxy-2-nonenal can modify proteins and DNA causing further damage [3]. Oxidation causes irreversible changes to protein structure and activity, while sulfur-containing amino acids are particularly susceptible to ROS-mediated damage [4]. ROS can also cause severe damage to cellular DNA, and the fate of the cell depends on the extent of DNA damage [5]. Therefore, regulating redox status in the living systems by maintaining appropriate levels of ROS is important for proper redox homeostasis $[1,6]$. Reduced form of glutathione (GSH) is a natural radical scavenger in the living systems that can protect cells from ROS-mediated oxidative damage. The ratio of GSH and oxidized form of glutathione (GSSG) is an indicator of the redox status of cells [7]. Expression of glutathione peroxidase $(\mathrm{GPx})$ is also known to upregulate at high $\mathrm{H}_{2} \mathrm{O}_{2}$ concentrations resulting from oxidative stress [8].

In addition to cellular endogenous antioxidant systems, natural antioxidants are important in controlling excess ROS 
which cause oxidative stress $[9,10]$. Phenolic antioxidants are widely distributed antioxidants in the plant kingdom, which can inhibit the oxidative damage caused by ROS. In vitro assays indicate that G. alypum phenolic extracts inhibit the oxidative damage to lipids, proteins, and DNA [11]. Phenolic compounds can neutralize ROS and inhibit enzymes responsible for the production of inflammation mediators [12].

Coconut oil meal is a by-product of coconut oil industry, which is mainly utilized as animal feed. In the dry process of extraction of coconut oil, dried coconut kernel (copra) is pressed to expel coconut oil, and remaining residue is known as coconut oil meal. We have reported that phenolic antioxidants in coconut oil meal can be used as food preservatives, and phenolic compounds present in coconut oil meal include gallic acid, chlorogenic acid, caffeic acid, ellagic acid, catechin, epigallocatechin, apigenin, genistein, and naringenin $[13,14]$.

Various oxidation products or modified products of macromolecules are monitored to assess the amount of ROS damage to macromolecules. TBARS levels and oxidation products of proteins have been monitored to measure the oxidative damage to lipids and proteins, respectively, in living systems [15]. ROS causes damage to DNA in living systems resulting in breakage of DNA strands. $\mathrm{H}_{2} \mathrm{O}_{2}$-induced mitochondrial DNA (mtDNA) damage in cultured cells has been studied by gel electrophoresis and real-time PCR experiments $[16,17]$. The present study was conducted to evaluate the effectiveness of CMPE in inhibiting the oxidative damage to macromolecules with in vitro and in vivo systems. A rat model was used to assess any toxic effects of CMPE.

\section{Materials and Methods}

2.1. Chemicals. Folin-Ciocalteu reagent, butylated hydroxy toluene (BHT), diphenyl-2-picrylhydrazyl (DPPH), Dulbecco's Modified Eagle's medium (DMEM), phosphate buffered saline, foetal bovine serum (FBS), and Penicillin/ Streptomycin were purchased from Sigma (St. Louis, MO). miScript SYBR Green PCR kit was purchased from Qiagen. SV Total RNA Isolation System, GSH/GSSG-Glo ${ }^{\mathrm{TM}}$ Assay kit, and CellTiter-Glo Assay kit were purchased from Promega. High Capacity cDNA Reverse Transcription Kit was purchased from Applied Biosystems. All other chemicals were purchased form Sigma or Fluka (Buchs, Switzerland).

\subsection{In Vitro Antioxidant Activity}

2.2.1. Sample Preparation and Evaluation of Total Phenol Content. Coconut oil meal samples were gifts from local mills in Western Province in Sri Lanka. Phenolic compounds of coconut oil meal were extracted with ethanol: water $(70: 30 \mathrm{v} / \mathrm{v})$, and total phenol contents were determined as previously reported [13].

2.2.2. Inhibition of Lipid Peroxidation. Sunflower oil-inwater emulsion was prepared by homogenizing $0.1 \mathrm{~g}$ of Tween $20,1.0 \mathrm{~g}$ of sunflower oil, and $50 \mathrm{~mL}$ of $10 \mathrm{mM}$ phosphate buffer at $100 \mathrm{rpm}$ for $2 \mathrm{~min}$. CMPE and butylated hydroxytoluene (BHT) were dissolved in equal parts of homogenate to reach $0.1 \mathrm{mg} / \mathrm{mL}$. The control was prepared with no added antioxidants, and all the mixtures were stored at $30^{\circ} \mathrm{C}$. Lipid peroxides were measured after storing for 21 days. $0.50 \mathrm{~mL}$ thiobarbituric acid (TBA) reagent (15\% trichloroacetic acid (TCA), $8 \%$ TBA in $0.05 \mathrm{~mol} / \mathrm{L} \mathrm{HCl}$ ) and BHT $(4 \mu \mathrm{L}, 0.2 \%)$ were added to $100 \mu \mathrm{L}$ of each homogenate and heated for $15 \mathrm{~min}$ at $95^{\circ} \mathrm{C}$. The mixtures were cooled and centrifuged $(380 \mathrm{~g} \times 20 \mathrm{~min})$. The absorbance of the supernatant was measured at $532 \mathrm{~nm}$ using Multiscan Go Spectrophotometer (Thermo Scientific), and the concentration of TBARS was determined against an MDA standard curve.

2.2.3. Inhibition of Protein Oxidation. Phosphate buffer $(0.2 \mathrm{M}, \mathrm{pH} 7.4,20 \mu \mathrm{L}), \mathrm{FeCl}_{3}(200 \mathrm{mM}, 20 \mu \mathrm{L})$, EDTA $(1 \mathrm{mM}, 20 \mu \mathrm{L})$, CMPE or gallic acid $(20,40,60,80,100,200$, $300,400,500 \mu \mathrm{g} / \mathrm{mL}, 100 \mu \mathrm{L}), \mathrm{H}_{2} \mathrm{O}_{2}(30 \mathrm{mM}, 20 \mu \mathrm{L})$, and ascorbic acid $(0.1 \mathrm{mM}, 20 \mu \mathrm{L})$ were mixed with BSA $(8 \mu \mathrm{g} /$ $\mathrm{mL}, 200 \mu \mathrm{L})$ and incubated for one hour. TCA $(30 \%$, $500 \mu \mathrm{L})$ was added to the mixture and centrifuged at $11000 \mathrm{~g}$ for $3 \mathrm{~min}$, and the protein pellet was separated. 2,4Dinitrophenyl hydrazine (2,4-DNPH) $(10 \mathrm{mM}$ in $2 \mathrm{M} \mathrm{HCl}$, $500 \mu \mathrm{L}$ ) was added to the pellet, mixed, and incubated at room temperature (RT) for $1 \mathrm{hr}$ in the dark while mixing every $10 \mathrm{~min}$. Then, TCA $(125 \mu \mathrm{L}, 20 \%)$ was added and centrifuged $(11000 \mathrm{~g} \times 3 \mathrm{~min})$. The pellet was separated, washed three times $(250 \mu \mathrm{L} \times 3)$ with ethanol: ethyl acetate mixture $(1: 1 \mathrm{v} / \mathrm{v})$, and incubated for $10 \mathrm{~min}$ at $\mathrm{RT}$, and pellet was separated by centrifugation $(11000 \mathrm{~g} \times 3 \mathrm{~min})$. The pellets were reconstituted in Guanidine solution $(150 \mu \mathrm{l}, 6 \mathrm{M})$ and centrifuged $(11000 \mathrm{~g} \times 3 \mathrm{~min})$. The absorbance of the supernatant was measured at $370 \mathrm{~nm}$. Inhibition of protein oxidation by CMPE was calculated according to the following formula: inhibition $\%=$ $[(\mathrm{A} 0-\mathrm{A} 1) / \mathrm{A} 0] \times 100 \%$ (where $\mathrm{A} 0$ is the absorbance of the reaction mixture with solvent system instead of CMPE or $\mathrm{GA}$, and $\mathrm{A} 1$ is the absorbance of the reaction mixture with CMPE or GA).

\subsubsection{Inhibition of Nicked DNA Formation. pET28a plasmid} DNA was extracted from JM109 strain of Escherichia coli cells using HiPurA ${ }^{\mathrm{TM}}$ Plasmid DNA Miniprep Purification Kit (HiMedia) according to the manufacturer recommendations. Purity of plasmid DNA preparations was determined based on A260 nm/A280 nm > 1.8, and integrity of plasmid DNA was confirmed by agarose gel electrophoresis. The plasmid DNA was supercoiled by incubating at $37^{\circ} \mathrm{C}$ for $1 \mathrm{hr}$ and cooling on ice. DNA (1500 ng), CMPE $(2 \mathrm{mg} / \mathrm{mL})$, $\mathrm{FeSO}_{4}(25 \mu \mathrm{M})$, EDTA $(100 \mu \mathrm{M})$, and $\mathrm{H}_{2} \mathrm{O}_{2}(2.5 \mathrm{mM})$ were mixed into a final volume of $20 \mu \mathrm{L}$ and incubated at $37^{\circ} \mathrm{C}$ for $1 \mathrm{hr}$. The DNA was analyzed by agarose gel electrophoresis and visualized with a UV transilluminator (Maestrogen). The negative control contained no added CMPE, $\mathrm{FeSO}_{4}$, or $\mathrm{H}_{2} \mathrm{O}_{2}$. The positive control contained all other reagents except CMPE. 


\subsection{Antioxidant Activity in Cultured Cells}

2.3.1. Treatment of HEp-2 Cells with CMPE. HEp-2 cells (ATCC ${ }^{\circledR}$ CCL-23 ${ }^{\mathrm{TM}}$ ) were grown in DMEM media with $10 \%$ FBS and $1 \%$ Penicillin/Streptomycin. HEp-2 is not a laryngeal cell line but is contaminated by HeLa (http://iclac. org/databases/cross-contaminations/). Cells at $80 \%$ confluence were split at $1 \times 10^{6}$ cells $/ \mathrm{mL}$ in a 24 -well culture dish and incubated for 4 hours to allow cell attachment prior to treatment with CMPE. Solvent (ethanol: water) of CMPE solution was evaporated completely, and CMPE was redissolved in distilled water to reach $125 \mathrm{mg} / \mathrm{mL}$. Aqueous solution of CMPE was filter-sterilized with $0.22 \mu \mathrm{m}$ sterile filter. Cultured cells were treated with $\mathrm{CMPE}$ at a final concentration of $0.5 \mathrm{mg} / \mathrm{mL}$ and incubated overnight at $37^{\circ} \mathrm{C}$ with $5 \% \mathrm{CO}_{2}$. Control was prepared by treating cells with water instead of CMPE.

2.3.2. Induction of Oxidative Stress in HEp-2 Cells. The media with CMPE or water were removed, and the cells were washed with $1 \mathrm{X}$ PBS $(500 \mu \mathrm{L})$. Oxidative stress was induced with $10,50,100,250 \mu \mathrm{M} \mathrm{H}_{2} \mathrm{O}_{2}$ for $1 \mathrm{hr}$ in $1 \mathrm{X}$ PBS $(500 \mu \mathrm{L})$ at $37^{\circ} \mathrm{C}$ and $5 \% \mathrm{CO}_{2}$.

2.3.3. Cell Viability Assay. After induction of oxidative stress, the medium was removed from the cells, and 1X PBS $(50 \mu \mathrm{L})$ was added. The CellTiter-Glo (Promega) reagent was thawed at $22^{\circ} \mathrm{C}$, and $50 \mu \mathrm{L}$ was added to each sample containing the stressed cells. The mixture was incubated at RT for $10 \mathrm{~min}$ after mixing the contents for $2 \mathrm{~min}$. The luminescence was measured using GloMax ${ }^{\circledR}$ 20/20 luminometer (Promega).

2.3.4. TBARS Assay for Lipid Peroxidation in Cultured Cells. Oxidative stress-induced cells were washed with 1X PBS $(500 \mu \mathrm{L})$ and incubated for $10 \mathrm{~min}$ at RT with $50 \mu \mathrm{L} 1 \mathrm{X}$ PLB [Tris- $\mathrm{HCl}$ (25 mM, pH 7.8), EDTA (2 mM), Glycerol (10\%), and Triton $\left.{ }^{\circledR} \mathrm{X}-100(1 \%)\right]$, and the lysate was centrifuged $(1000 \mathrm{~g}, 3 \mathrm{~min})$ to separate the supernatant. TBARS assay was performed as described above.

2.3.5. Protein Carbonyl Assay in Cultured Cells. TCA $(125 \mu \mathrm{L}, 30 \%)$ was mixed with the supernatant of the lysate from stress-induced cells prepared as above $(50 \mu \mathrm{L})$, and the mixture was centrifuged $(11000 \mathrm{~g} \times 3 \mathrm{~min})$. The supernatant was decanted, 2,4-DNPH $(125 \mu \mathrm{L}, 10 \mathrm{mM})$ was added to the pellet, and the mixture was incubated in the dark for $1 \mathrm{hr}$ at RT. Then, the procedure described above for protein carbonyl assay was repeated, and the content of protein carbonyl was calculated as described previously [18].

2.3.6. Mitochondrial DNA Damage Assay in Cultured Cells. Total DNA of HEp-2 cells was purified using HiPurA ${ }^{\mathrm{TM}}$ Blood Genomic DNA Miniprep Purification Kit (HiMedia) from cells treated as mentioned above and was stored at $-20^{\circ} \mathrm{C}$. The purity of DNA was determined as detailed above. Amplification of the longer fragment of mitochondrial DNA
(mtDNA), compared to a shorter fragment in the same region, was monitored by consecutive real-time qPCR with QuantiTect SYBR Green PCR kit (Qiagen) using StepOne Real-Time PCR system (Applied Biosystems) to quantify DNA damage in the D-Loop region from each treatment condition. The forward and reverse primer sequences for long fragment were $5^{\prime}$ CTGTTCTTTCATGGGGAAGC $3^{\prime}$ and $5^{\prime}$ AAAGTGCATACCGCCAAAAG 3', respectively. The forward and reverse primer sequences for short fragment were $5^{\prime}$ CCCTAACACCAGCCTAACCA3' and 5'AAAGTGCATACCGCCAAAAG 3', respectively [17]. The total reaction volume was $10 \mu \mathrm{L}$ with $500 \mathrm{nM}$ of each forward and reverse primer and $0.4 \mu \mathrm{g}$ of template DNA. The cycling conditions included denaturation at $95^{\circ} \mathrm{C}$ for $15 \mathrm{~min}$ followed by 40 cycles of $94^{\circ} \mathrm{C}$ for $15 \mathrm{~s}, 60^{\circ} \mathrm{C}$ for $10 \mathrm{~s}$, and $72^{\circ} \mathrm{C}$ for $10 \mathrm{~s}$ final extension or $72^{\circ} \mathrm{C}$ for $50 \mathrm{~s}$ extension for the small fragment and large fragment, respectively. The specificity was confirmed by melting curve analysis and gel electrophoresis. Each sample was assayed in duplicate. The ratio of intact DNA was calculated by the $2^{-\Delta \Delta} \mathrm{Cp}$ method based on the difference in the mean crossing point $(\mathrm{Cp})$ values $(\Delta \mathrm{Cp})$ for the long $[\Delta \mathrm{Cp}$ (long) $]$ and the short fragment $[\Delta \mathrm{Cp}$ (short) $]$ of respective untreated versus each treated condition. $\Delta \mathrm{Cp}$ (long) $=\mathrm{Cp}_{\left(\mathrm{H} 2 \mathrm{O}+\mathrm{H}_{2} \mathrm{O} 2\right)}-\mathrm{Cp}_{(\mathrm{CMPE}+\mathrm{H} 2 \mathrm{O} 2)} \Delta \mathrm{Cp}$ (short) $=\mathrm{Cp}_{(\mathrm{H} 2 \mathrm{O}+\mathrm{H} 2 \mathrm{O} 2)}-\mathrm{Cp}_{(\mathrm{CMPE}+\mathrm{H} 2 \mathrm{O} 2) \text {. }}$

The DNA damage was calculated as the number of lesions per $10 \mathrm{~kb}$ mtDNA region using the following formula: lesion

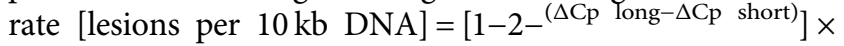
$[10000 \mathrm{bp} /($ size of long fragment bp)].

2.3.7. Glutathione Assay in Cultured Cells. Oxidative stressinduced HEp-2 cells were washed with 1X PBS $(500 \mu \mathrm{L})$, and Lysis Reagent $(50 \mu \mathrm{L})$ was added, mixed by pipetting, and incubated at RT for $5 \mathrm{~min}$. GSH : GSSG ratio was determined using GSH/GSSG-Glo ${ }^{\mathrm{TM}}$ Assay kit (Promega) according to manufacturer's instructions.

2.3.8. Analysis of Glutathione Peroxidase (GPx) Expression. Total RNA from HEp-2 cells was extracted using SV Total RNA Isolation System (Promega) according to manufacturer's instructions, and purity $\left(A_{260} / A_{280}>2.0\right)$ was confirmed as detailed above. cDNA synthesis was carried out for $1 \mu \mathrm{g}$ of RNA using High Capacity cDNA Reverse Transcription Kit (Applied Biosystems ${ }^{\mathrm{TM}}$ ). Primers against GPx were designed using NCBI BLASTN to span exon junctions and validated by USCS in silico PCR. Absence of homo- and heterodimer formation of primers was validated by IDT OligoAnalyzer. Forward and reverse primers for GPx were 5' GAGGGCAAAATCCCGGTGAC $3^{\prime}$ and 5' CAACATCGTTGCGACACACC 3', respectively (NCBI accession code: NC-00000312). The house keeping gene GAPDH was detected as previously reported [19]. Amplification specificity was confirmed by meting curve analysis and gel electrophoresis. PCR amplification efficiency was determined by standard curve analysis according to a previously published method [19]. The efficiency of PCR amplification of GAPDH and GPx is 
$111 \%$ and $103 \%$, respectively. Thus, gene expression analysis was done without using amplification efficiency calculations.

2.4. Animal Study. Seven-week-old male Wistar rats (weighing 240-300 g) were selected from the Medical Research Institute, Colombo, Sri Lanka. The animals were housed in cages in a room maintained at $25 \pm 1^{\circ} \mathrm{C}$ with a $12 \mathrm{~h}$ light and dark cycle. Prior to the commencement of the experiment, rats were acclimatized to the basal diet for 6 days. Then the rats were randomly assigned to experimental groups (7 rats/group).

The solvent was removed from CMPE, and the resultant residue was dissolved in distilled water. Rats were orally fed daily with CMPE $(1 \mathrm{~mL})$ to reach $400 \mathrm{mg} \mathrm{CMPE} / \mathrm{kg}$ of body weight for 150 days as reported [20]. The rats in the control group were orally fed with distilled water $(1 \mathrm{~mL})$ daily. The two groups were fed with a semisynthetic diet recommended by WHO. Ad libitum access to water and diet was provided throughout the study. Body weights and feed intake were measured weekly. The rats were fasted for $10-12 \mathrm{~h}$, and blood $(1 \mathrm{~mL})$ was drawn from the tail vein on the day before sample collection (day 0 ), day 30 , day 90, day 120, and Day 150. Serum trolox equivalent antioxidant capacity and DPPH radical scavenging activity were monitored over 150-day period based on reported methods [21, 22] with modifications [20]. Plasma TBARS contents and protein carbonyl contents were determined as previously described [20, 23]. Alanine aminotransferase (ALT) and aspartate amino transferase (AST) levels in serum on day 0 and day 150 were detected as previously described [20]. All experimental procedures with rats were approved by the Ethics Review Committee of University of Kelaniya.

2.5. Statistical Analysis. Two biological replicates were carried out for all experiments except animal studies. Twosample $t$-test was carried out for the determination of significant differences $(p \leq 0.05)$ between the mean values of independent variables. Gene expression analysis was carried out in triplicate. Relative quantification method $(\Delta \Delta \mathrm{Cq})$ was used to analyze the gene expression data. $\Delta$ Cq values for GPx expression were obtained against GAPDH as the reference gene. $\Delta \Delta \mathrm{Cq}$ was calculated by subtracting $\Delta \mathrm{Cq}$ values of the CMPE-treated, oxidative stress-induced and untreated, and oxidative stress-induced samples. The fold change of expression was calculated using the $2^{-\Delta \Delta \mathrm{Cq}}$ method. Statistical significance for differentially expressed targets was determined based on the standard error of mean (SEM) of $\Delta \mathrm{Cq}$ using independent $t$-test $(p \leq 0.05)$.

\section{Results and Discussion}

3.1. Total Phenolic Content and In Vitro Antioxidant Activity. Total phenolic content of coconut oil meal resulting from four successive extractions is $2527 \pm 51 \mathrm{mg}$ gallic acid eqv./ $\mathrm{kg}$ dried meal. Lipids are among the most sensitive macromolecules susceptible to attack by ROS. Reaction of ROS with lipid components of biomembranes subsequently induces cell death [24]. In vitro experiments of the present study indicate there is no significant difference in the TBARS levels measured as MDA levels in the BHT- or CMPE-added sunflower oil-in-water emulsions up to 16 days. Both BHT- and CMPE-added sunflower oil emulsions maintained TBARS levels below $1.5 \mu \mathrm{g} / \mathrm{mL}$ up to 16 days, while TBARS levels of the control with no added antioxidants exceed this value during days 4-6 (Figure 1(a)). Aldehydes or ketones formed as a result of protein oxidation can react with 2,4-DNPH to form hydrazones that can be measured by colorimetric methods. Figure 1(b) shows that the inhibitory activity of protein carbonyl formation with respect to the control with no added antioxidants increases with the antioxidant concentration, and the inhibition percentage of CMPE is closely comparable with that of gallic acid.

A single strand break (nick) in DNA can lead to different DNA conformations. Nicked DNA can be formed due to oxidative damage resulting in changes to the superhelical conformation to form nicked circular DNA. In agarose gel electrophoresis, nicked DNA moves slowly from the loading position (top) in Figure 2 to travel a shorter distance compared to supercoiled DNA. Figure 2 shows that, in the absence of antioxidants (BHT or CMPE), $\mathrm{H}_{2} \mathrm{O}_{2}$ induces formation of nicked DNA possibly by oxidative DNA damage and this damage is inhibited by BHT and CMPE.

3.2. Antioxidant Activity of CMPE in Cultured Cells. Oxidative damage in vivo was assessed in HEp-2 cells treated with $\mathrm{H}_{2} \mathrm{O}_{2}$ and $\mathrm{CMPE}$ while maintaining the cell viability above $80 \%$ [25]. Consistent with ISO recommendations, cell viability was above $98 \%$ at $100 \mu \mathrm{M} \mathrm{H}_{2} \mathrm{O}_{2}$ and $0.5 \mathrm{mg} / \mathrm{mL}$ of CMPE.

Even though TBARS levels measured in chemical systems as MDA after exposing to oxidative stress conditions directly reflect the amount of oxidative damage to the lipid substrate, TBARS assay is less reliable as an indicator of lipid peroxidation in cells and body fluids [26]. Sugars, amino acids, and bilirubin are also reactive towards TBA [27]. However, measuring TBARS levels with respect to proper controls provides an idea about the effect of antioxidants on the levels of TBARS. The TBARS levels produced in response to oxidative damage of lipids in HEp-2 cells were assessed using a concentration series of $\mathrm{H}_{2} \mathrm{O}_{2}$. TBARS formation in HEp-2 cells gradually increased with the $\mathrm{H}_{2} \mathrm{O}_{2}$ concentration $(10 \mu \mathrm{M}, 50 \mu \mathrm{M}$, and $100 \mu \mathrm{M})$ compared to the control without $\mathrm{H}_{2} \mathrm{O}_{2}$. Pretreatment with $\mathrm{CMPE}(0.5 \mathrm{mg} / \mathrm{mL})$ significantly $(p<0.05)$ inhibited lipid peroxidation at all the $\mathrm{H}_{2} \mathrm{O}_{2}$ concentrations (Figure 3(a)).

One of the most deleterious effects of protein oxidation is enzyme deactivation. In vitro studies using $\alpha$-amylase from Bacillus species as a model protein have shown that oxidative process affects the catalytic activity [28]. Protein carbonyl content is the most general indicator and the most commonly used marker of protein oxidation, and accumulation of protein carbonyls has been observed in several human diseases [29]. Protein carbonyl formation assessed with 2, 4DNPH increased gradually with the $\mathrm{H}_{2} \mathrm{O}_{2}$ concentration. Pretreatment with CMPE $(0.5 \mathrm{mg} / \mathrm{mL})$ significantly 


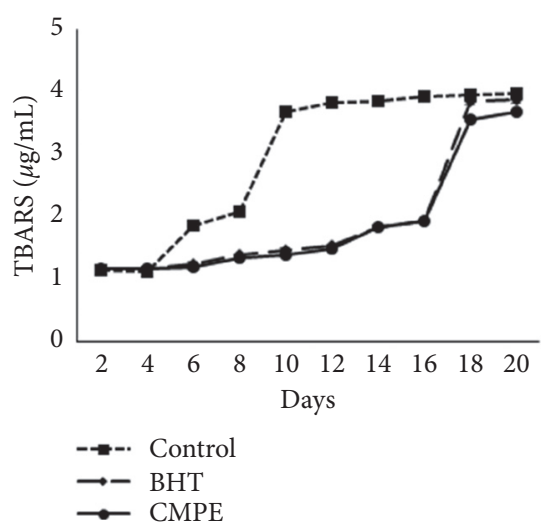

(a)

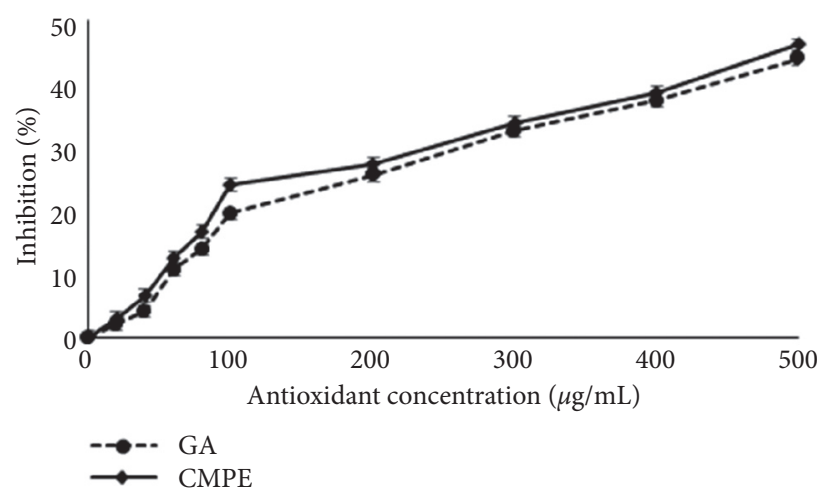

(b)

FIGURE 1: In vitro protective effect of CMPE on (a) lipid peroxidation and (b) protein oxidation.

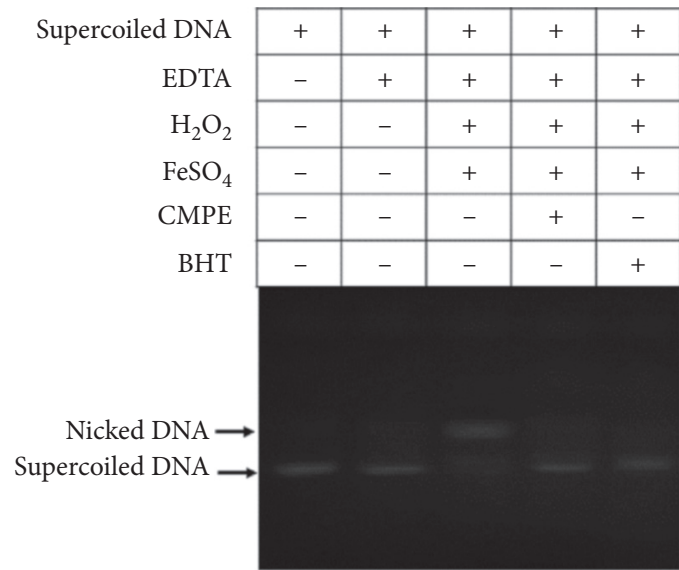

FIGURE 2: Inhibition of nicked DNA formation by CMPE and BHT.

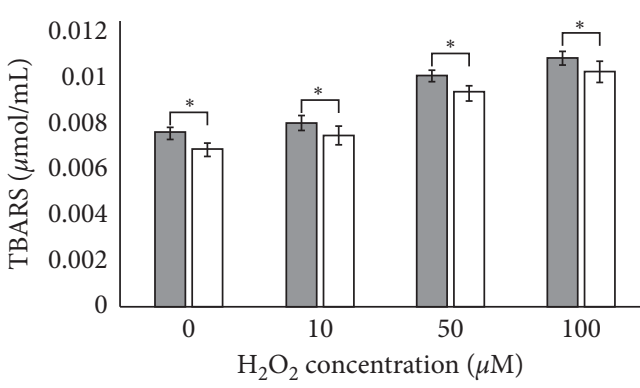

No CMPE

$0.50 \mathrm{mg} / \mathrm{mL}$

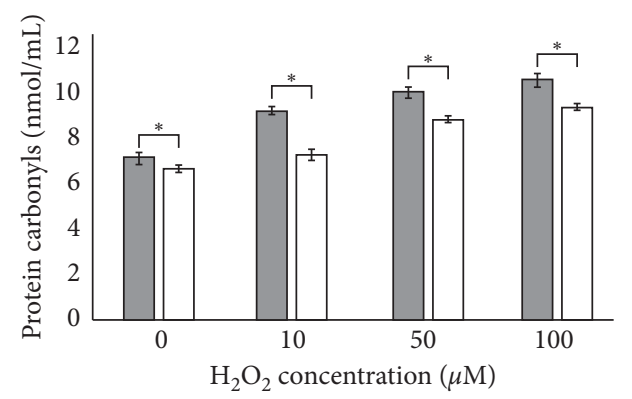

No CMPE

$0.50 \mathrm{mg} / \mathrm{mL}$

(a)

(b)

FIGURE 3: Inhibition of oxidative damage in HEp-2 cells by CMPE: (a) inhibition of lipid peroxidation, (b) inhibition of protein carbonylation.

$(p<0.05)$ inhibited the protein oxidation at all $\mathrm{H}_{2} \mathrm{O}_{2}$ concentrations (Figure 3(b)).

DNA damage in HepG2 cells has been tested after exposing cells at 25 and $50 \mu \mathrm{M} \mathrm{H}_{2} \mathrm{O}_{2}$ concentrations for different time periods up to $24 \mathrm{hrs}$. Results indicate that DNA damage increases with $\mathrm{H}_{2} \mathrm{O}_{2}$ concentration and exposure time [30]. Mitochondria have a circular genome that encodes RNA and proteins required for oxidative phosphorylation. Formation of ROS during oxidative phosphorylation is inevitable, and due to this proximity of the source of ROS 
production, $\mathrm{mtDNA}$ is more prone to oxidative damage than nuclear DNA. D-loop region of the mtDNA is a hot spot for ROS-derived damage, and PCR methods have been developed to detect the DNA damage [17]. The amplification of a long fragment of mtDNA compared to a shorter fragment in the same region was used to quantify the amount of damage based on the premise that DNA damage would result in less PCR product formation for the long fragment compared to undamaged DNA. Lesions/10 kb DNA are significantly lower $(p \leq 0.05)$ for CMPE-treated cells compared to untreated cells ( $7.65 \pm 0.06$ vs $9.37 \pm 0.60$ ), suggesting a protective effect in vivo from pretreatment with polyphenolic antioxidants extracted from coconut meal.

GSH/GSSG ratio is considered to be the best indicator that reflects the antioxidant capacity in cells. GSH scavenges ROS; producing GSSG and GSH/GSSG ratios of 100 to 1 may be possible depending on the redox conditions in the mammalian cells [31]. Several values for this ratio for different oxidants such as diamide, $\mathrm{H}_{2} \mathrm{O}_{2}$, and different oxygen concentrations in different cultured cells have been reported $[32,33]$. The GSH/GSSG ratio of the oxidative stress-induced cultured HEp- 2 cells pretreated with CMPE is significantly $(p \leq 0.05)$ higher compared to cells that were not pretreated with CMPE (Figure 4).

Glutathione peroxidase (GPx) is a major peroxide scavenging enzyme. Decreased GPx activity can be observed in tissues under oxidative stress. Accumulation of peroxides due to inactivation of GPx triggers the expression of GPx [34]. To evaluate the effect of CMPE on the expression of endogenous oxidative stress response genes, we also quantified the expression of GPx against GAPDH as a housekeeping gene, by qRT-PCR after induction of oxidative stress with or without pretreatment with CMPE. Fold change of expression presented as log values to the base 2, where a fold change $>1.5$ was considered as upregulation and that $<0.5$ was considered as downregulation; for samples exposed to $\mathrm{H}_{2} \mathrm{O}_{2}$ with and without CMPE pretreatment, it was 0.91 and 1.14, respectively, indicative of no differential expression with no significant difference between these two values. Absence of a significant difference in the expression of GPx in the cells treated with CMPE $(0.5 \mathrm{mg} / \mathrm{mL})$ and untreated cells suggests that there is a role for exogenous antioxidants such as CMPE to regulate the cellular oxidative stress responses without affecting the expression of oxidative stress response genes.

3.3. Animal Model. In vivo study was further extended to the animal model in order to check the long-term effect of oral feeding of CMPE on the serum and plasma antioxidant status and to evaluate any toxic effects. Both DPPH radical scavenging activity and trolox equivalent antioxidant capacity improved and stabilized roughly during 120-150 days (Table 1). Similar observations have been made for other plant extracts containing similar phenolic substances [20]. Plasma protein carbonyl content of the rats fed with CMPE $(18.9 \pm 1.9 \mu \mathrm{mol} / \mathrm{L})$ was significantly lower $(p \leq 0.05)$ than that of control rats $(23.4 \pm 3.8 \mu \mathrm{mol} / \mathrm{L})$ on day 150 . However, there was no significant difference in the plasma TBARS

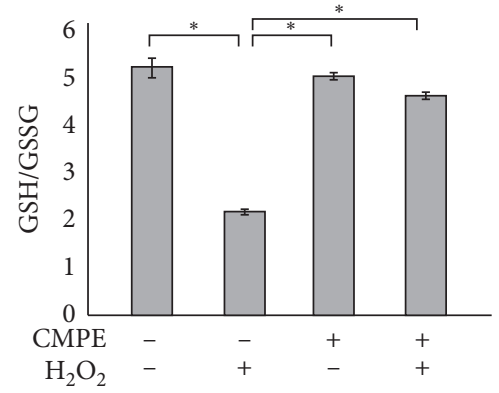

Figure 4: Effect of CMPE on the GSH/GSSG ratio of oxidative stress-induced HEp-2 cells.

TABLE 1: Serum DPPH radical scavenging activity and trolox equivalent antioxidant capacity of Wistar rats during 150 days of oral feeding of CMPE.

\begin{tabular}{lllll}
\hline & \multicolumn{2}{c}{ DPPH inhibition $\%$} & \multicolumn{2}{c}{$\begin{array}{c}\text { Trolox equivalent } \\
(\mu \mathrm{mol} \mathrm{L})^{-1}\end{array}$} \\
& Control & CMPE & Control & CMPE \\
\hline 0 & $11 \pm 1^{\text {ar }}$ & $11 \pm 1^{\text {ar }}$ & $15 \pm 2^{\text {aq }}$ & $15 \pm 2^{\text {aq }}$ \\
30 & $10 \pm 1^{\text {br }}$ & $16 \pm 1^{\text {aq }}$ & $13 \pm 1^{\text {aq }}$ & $14 \pm 2^{\text {ar }}$ \\
90 & $33 \pm 4^{\text {bp }}$ & $37 \pm 2^{\text {ap }}$ & $13 \pm 2^{\text {bq }}$ & $15 \pm 1^{\text {aq }}$ \\
120 & $35 \pm 5^{\text {ap }}$ & $36 \pm 4^{\text {ap }}$ & $20 \pm 1^{\text {bp }}$ & $22 \pm 1^{\text {ap }}$ \\
150 & $30 \pm 4^{\text {bq }}$ & $36 \pm 2^{\text {ap }}$ & $20 \pm 1^{\text {bp }}$ & $23 \pm 2^{\text {ap }}$ \\
\hline
\end{tabular}

Each data point represents the mean $\pm \mathrm{SD}(n=7)$. Different letters ( $\mathrm{a}$ and $\mathrm{b}$ ) indicate a significant difference $(p \leq 0.05)$ in rows. Different letters ( $\mathrm{p}, \mathrm{q}$, and r) indicate a significant difference $(p \leq 0.05)$ in columns.

TABLE 2: ALT and AST levels in serum from Wistar rats with oral feeding of CMPE.

\begin{tabular}{lcccc}
\hline \multirow{2}{*}{ Group } & \multicolumn{2}{c}{ ALT (U/L) } & \multicolumn{2}{c}{ AST (U/L) } \\
& Day 0 & Day 150 & Day 0 & Day 150 \\
\hline Control (distilled water) & $27 \pm 2^{*}$ & $28 \pm 2^{*}$ & $28 \pm 2^{*}$ & $29 \pm 3^{*}$ \\
CMPE-fed & $29 \pm 2^{*}$ & $29 \pm 2^{*}$ & $30 \pm 3^{*}$ & $30 \pm 3^{*}$ \\
\hline
\end{tabular}

Data represent mean $\pm \mathrm{SD}(n=7) .{ }^{*}$ No significant difference was observed between the values.

contents of the rats fed with CMPE $(0.05 \pm 0.01 \mu \mathrm{mol} / \mathrm{L})$ compared to control rats $(0.06 \pm 0.01 \mu \mathrm{mol} / \mathrm{L})$ on day 150 . Serum AST and ALT levels of the rats are given in Table 2. Feeding rats daily with CMPE for 150 days did not change the serum AST and ALT levels significantly, suggesting that daily feeding of the tested dose of CMPE does not cause any toxic effects.

\section{Conclusions}

CPME, rich in phenolic antioxidants, can protect macromolecules against oxidative damage in vivo. Several agerelated diseases such as cardiovascular disease, cancer, and Parkinson's disease are closely connected to oxidative damage to macromolecules. Therefore, intake of coconut oil meal antioxidants may provide protection against such diseases. As coconut oil meal is a cheap by-product of coconut oil industry, nutritional supplements or nutritional 
food preparations can be designed based on coconut oil meal, which might provide a nutraceutical effect against these diseases.

\section{Data Availability}

The data used to support the findings of this study are included within the article.

\section{Conflicts of Interest}

All the authors declare no conflicts of interest.

\section{Acknowledgments}

The authors would like to thank Prof. Preeth Zoyza of the Faculty of Medicine, University of Colombo, for her support in cell culture. The work was funded by National Science Foundation, Sri Lanka (RG/2015/AG/03), and University of Kelaniya Research (Grant RP/03/02/06/03/2018).

\section{References}

[1] A. A. Alfadda and R. M. Sallam, "Reactive oxygen species in health and disease," Biomed Research International, vol. 2012, Article ID 936486, 14 pages, 2012.

[2] R. H. Burdon, "Superoxide and hydrogen peroxide in relation to mammalian cell proliferation," Free Radical Biology and Medicine, vol. 18, no. 4, pp. 775-794, 1995.

[3] A. Ayala, M. F. Muñoz, and S. Argüelles, "Lipid peroxidation: production, metabolism, and signaling mechanisms of malondialdehyde and 4-hydroxy-2-nonenal," Oxidative Medicine and Cellular Longevity, vol. 2014, Article ID 360438, 31 pages, 2014.

[4] B. Ezraty, A. Gennaris, F. Barras, and J.-F. Collet, "Oxidative stress, protein damage and repair in bacteria," Nature Reviews Microbiology, vol. 15, no. 7, pp. 385-396, 2017.

[5] A. Barzilai and K.-I. Yamamoto, "DNA damage responses to oxidative stress," DNA Repair, vol. 3, no. 8-9, pp. 1109-1115, 2004.

[6] B. Poljsak, D. Suput, and I. Milisav, "Achieving the balance between ROS and antioxidants: when to use the synthetic antioxidants," Oxidative Medicine and Cellular Longevity, vol. 2013, Article ID 956792, 11 pages, 2013.

[7] J. B. Owen and D. A. Butterfield, "Measurement of oxidized/ reduced glutathione ratio," Methods in Molecular Biology (Clifton, N.J.), vol. 648, pp. 269-277, 2010.

[8] A. H. Wagner, O. Kautz, K. Fricke et al., "Upregulation of glutathione peroxidase offsets stretch-induced proatherogenic gene expression in human endothelial cells," Arteriosclerosis, Thrombosis and Vascular Biology, vol. 29, no. 11, pp. 18941901, 2009.

[9] L. He, T. He, S. Farrar, L. Ji, T. Liu, and X. Ma, "Antioxidants maintain cellular redox homeostasis by elimination of reactive oxygen species," Cellular Physiology and Biochemistry, vol. 44, no. 2, pp. 532-553, 2017.

[10] M. Stańczyk, J. Gromadzińska, and W. Wąsowicz, "Roles of reactive oxygen species and selected antioxidants in regulation of cellular metabolism," International Journal of Occupational Medicine and Environmental Medicine, vol. 18, no. 1, pp. 15-26, 2005.

[11] H. Bouriche, S. Kada, A Senator et al., "Phenolic content and biomolecule oxidation protective activity of Globularia alypum extracts," Brazillian Archives of Biology and Technology, vol. 60, Article ID e17160409, 2017.

[12] T. Hussain, B. Tan, Y. Yin, F. Blachier, M. C. B. Tossou, and N. Rahu, "Oxidative stress and inflammation: what polyphenols can do for us?" Oxidative Medicine and Cellular Longevity, vol. 2016, Article ID 7432797, 9 pages, 2016.

[13] K. N. Seneviratne, W. C. Prasadani, and B. Jayawardena, "Phenolic extracts of coconut oil cake: a potential alternative for synthetic antioxidants," Food Science and Technology, vol. 36, no. 4, pp. 591-597, 2016.

[14] C. M. Senanayake, C. H. Algama, R. L. Wimalasekara, W. N. M. T. D. N. Weerakoon, N. Jayathilaka, and K. N. Seneviratne, "Improvement of oxidative stability and microbial shelf life of vanilla cake by coconut oil meal and sesame oil meal phenolic extracts," Journal of Food Quality, vol. 2019, Article ID 1263629, 8 pages, 2019.

[15] S. Cecchini, G. Piccione, C. Saoca, G. Giangrosso, A. R. Caputo, and F. Fazio, "Redox status, lipid peroxidation and protein oxidation levels in small ruminants," Journal of Animal and Feed Sciences, vol. 27, no. 1, pp. 81-85, 2018.

[16] C. Andreoli, P. Leopardi, S. Rossi, and R. Crebelli, "Processing of DNA damage induced by hydrogen peroxide and methyl methanesulfonate in human lymphocytes: analysis by alkaline single cell gel electrophoresis and cytogenetic methods," Mutagenesis, vol. 14, no. 5, pp. 497-504, 1999.

[17] O. Rothfuss, T. Gasser, and N. Patenge, "Analysis of differential DNA damage in the mitochondrial genome e mploying a semi-long run real-time PCR approach," Nucleic Acids Research, vol. 38, no. 4, p. e24, 2010.

[18] A. Z. Reznick and L. Packer, "Oxidative damage to proteins: spectrophotometric method for carbonyl assay," Methods in Enzymology, vol. 233, pp. 357-363, 1994.

[19] H. Hapugaswatta, P. Amarasena, R. Premaratna, K. N. Seneviratne, and N. Jayathilaka, "Differential expression of microRNA, miR-150 and enhancer of zeste homolog 2 (EZH2) in peripheral blood cells as early prognostic markers of severe forms of dengue," Journal of Biomedical Sciences, vol. 27 , no. 1 , p. $25,2020$.

[20] C. M. Senanayake, H. Hapugaswatta, N. Jayathilaka, and K. N. Seneviratne, "Phenolic extracts of the leaves of Psidium guineense Sw. improve the shelf life of sunflower oil and baked cake and antioxidant status of Wistar rats," Journal of Food Biochemistry, vol. 42, Article ID e12632, 2018.

[21] R. Re, N. Pellegrini, A. Proteggente, A. Pannala, M. Yang, and C. Rice-Evans, "Antioxidant activity applying an improved ABTS radical cation decolorization assay," Free Radical Biology and Medicine, vol. 26, no. 9-10, pp. 1231-1237, 1999.

[22] J. Chrzczanowicz, A. Gawron, A Zwolinska et al., "Simple method for determining human serum 2,2-diphenyl-1-picrylhydrazyl (DPPH) radical scavenging activity-Possible application in clinical studies on dietary antioxidants," Clinical Chemistry and Laboratory Medicine, vol. 46, pp. 342-349, 2008.

[23] R. L. Levine, J. A. Williams, E. P. Stadtman, and E. Shacter, "Carbonyl assays for determination of oxidatively modified proteins," Methods in Enzymology, vol. 233, pp. 346-357, 1994.

[24] L.-J. Su, J.-H. Zhang, H Gomez et al., "Reactive oxygen species-induced lipid peroxidation in apoptosis, autophagy, and ferroptosis," Oxidative Medicine and Cellular Longevity, vol. 2019, Article ID 5080843, 13 pages, 2019.

[25] ISO 10993-5:2009, Biological Evaluation of Medical Devices. Part 5: Tests for in Vitro Cytotoxicity, International Organization for Standardization, Geneva, Switzerland, 2009. 
[26] J. M. C. Gutteridge, "Aspects to consider when detecting and measuring lipid peroxidation," Free Radical Research Communications, vol. 1, no. 3, pp. 173-184, 1986.

[27] E. A. Meagher and G. A. FitzGerald, "Indices of lipid peroxidation in vivo: strengths and limitations," Free Radical Biology and Medicine, vol. 28, no. 12, pp. 1745-1750, 2000.

[28] A. M. N. Silva, S. L. Marçal, R. Vitorino, M. R. M. Domingues, and P. Domingues, "Characterization of in vitro protein oxidation using mass spectrometry: a time course study of oxidized alpha-amylase," Archives of Biochemistry and Biophysics, vol. 530, no. 1, pp. 23-31, 2013.

[29] B. S. Berlett and E. R. Stadtman, "Protein oxidation in aging, disease, and oxidative stress," Journal of Biological Chemistry, vol. 272, pp. 20313-20316, 1997.

[30] G. Benhusein, E. Mutch, S. Aburawi, and F. Williams, "Genotoxic effect induced by hydrogen peroxide in human hepatoma cells using comet assay," Libyan Journal of Medicine, vol. 5, no. 1, p. 4637, 2010.

[31] O. Zitka, S. Skalickova, J. Gumulec et al., "Redox status expressed as GSH: GSSG ratio as a marker for oxidative stress in paediatric tumour patients," Oncology Letters, vol. 4, no. 6, pp. 1247-1253, 2012.

[32] P. K. Prasai, B. Shrestha, A. W. Orr, and C. B. Pattillo, "Decreases in GSH:GSSG activate vascular endothelial growth factor receptor 2 (VEGFR2) in human aortic endothelial cells," Redox Biology, vol. 19, pp. 22-27, 2019.

[33] M. Goto, H. Miwa, K Suganuma et al., "Adaptation of leukemia cells to hypoxic condition through switching the energy metabolism or avoiding the oxidative stress," BMC Cancer, vol. 14, p. 76, 2014.

[34] Y. Miyamoto, Y. H. Koh, Y. S Park et al., "Oxidative stress caused by inactivation of glutathioneperoxidase and adaptive responses," Biological Chemistry, vol. 384, no. 4, pp. 567-574, 2003. 